\title{
PENGARUH INDIVIDUAL CAPABILITY DAN MOTIVASI TEHADAP KINERJA KARYAWAN PADA PT. BALINDO MANUNGGAL BERSAMA KOTA PALU
}

\author{
Ni Made Mariani \\ Lina Mahardiana \\ Risnawati \\ Jurusan Manajemen, Fakultas Ekonomi, Universitas Tadulako \\ E-mail: marianimade111@gmail.com
}

\begin{abstract}
This study aims to determine and analyze simultaneous influence of individual capability and motivation on the performance of employees at PT. Balindo Manunggal Bersama; to analyze partial influence of individual capability and motivation on employees' performance at PT. Balindo Manunggal Bersama. This study uses quantitative approach to explain the relationship between two or more variables studied with a sample of 32 employees. Data analysis technique used is multiple linear regressions. The results of hypothesis testing show that: sig. F value of $0.000<0.05$ means that individual capability and motivation simultaneously have significant influence on employee performance; the value of significance level $t$ sig. $0,000<\alpha 0.05$ shows that individual capability partially has significant influence on employee performance; also, motivation partially has significant influence on employee performance with the significance level of t sig. 0,000 $<\alpha 0.05$.
\end{abstract}

Keywords: individual capability, motivation, and performance

\section{ABSTRAK}

Penelitian ini bertujuan: (1) Untuk mengetahui dan menganalisis apakah Individual Capability dan Motivasi berpengaruh secara serempak terhadap kinerja karyawan pada PT. Balindo Manunggal Bersama; (2) Untuk mengetahui dan menganalisis apakah Individual Capability berpengaruh secara parsial terhadap kinerja karyawan pada PT. Balindo Manunggal Bersama; (3) Untuk mengetahui dan menganalisis apakah Motivasi berpengaruh secara parsial terhadap kinerja karyawan pada PT. Balindo Manunggal Bersama. Penelitian ini menggunakan penelitian kuantitatif yang merupakan penelitian yang bertujuan untuk menjelaskan hubungan antara dua variabel atau lebih dengan sampel 32 karyawan dan teknik analisis data yang digunakan adalah regresi linear berganda. Hasil analisis dan pengujian hipotesis dapat disimpulkan bahwa: (1) berdasarkan hasil uji regresi diperoleh sig. $F$ sebesar 0,000 < 0,05, yang dapat diartikan bahwa variabel Individual Capability dan Motivasi secara serempak berpengaruh signifikan terhadap variabel kinerja karyawan; (2) berdasarkan hasil uji regresi diperoleh variabel Individual Capability memiliki tingkat signifikasi t sig. 0,000< $\alpha 0,05$, yang dapat diartikan bahwa variabel Individual Capability secara parsial berpengaruh signifikan terhadap kinerja karyawan; (3) berdasarkan hasil uji regresi diperoleh variabel Motivasi memiliki tingkat signifikasi $t$ sig. $0,000<\alpha$ 0,05, yang dapat diartikan bahwa variabel Motivasi secara parsial berpengaruh signifikan terhadap kinerja karyawan.

Kata kunci: individual capability, motivasi, dan kinerja

\section{PENDAHULUAN}

Tingkat persaingan pada dunia bisnis semakin berkembang pesat, untuk menghadapi hal tersebut perusahaan dituntut dapat memberdayakan sumber daya dengan baik. Sumber daya yang dimiliki perusahaan salah satunya adalah sumber daya manusia. Sumber daya manusia merupakan aset terpenting dalam perusahaan, oleh karena itu perlu pengelolaan khusus terhadap sumber daya manusia. "Manajemen sumber daya manusia adalah penarikan, seleksi, pengembangan, pemeliharaan, dan penggunaan sumber daya manusia untuk mencapai baik tujuan -tujuan individu maupun organisasi” Handoko (2011:4). 
Sumber daya manusia merupakan aset yang berharga bagi perusahaan, oleh karena itu SDM perlu dikelola dengan baik melalui peningkatan dan pengembangan pengetahuan, skill, dan kompetensi sehingga memberikan nilai tambah intelektual karyawan. Mangkunegara dalam Swastari (2013) mengatakan bahwa sumber daya manusia di perusahaan perlu dikelola secara profesional agar terwujud antara kebutuhan pegawai dengan tuntutan dan kemampuan organisasi perusahaan. Dengan pengelolaan SDM dalam perusahaan diharapkan mampu menciptakan sumber daya manusia yang professional dan produktif. Keunggulan kompetitif perusahaan ditentukan oleh mutu sumber daya manusia.

PT. Balindo Manunggal Bersama adalah sebuah perusahaan swasta yang bergerak di bidang pemasaran automotif khususnya penjualan mobil Honda beserta suku cadangnya di kota palu. Maka selain melakukan pemasaran, pihak perusahaan juga memberikan pelayanan terhadap konsumen. Sehingga mereka berkewajiban memberikan pelayanan yang profesional dengan cara menyediakan karyawan yang mempunyai kredibilitas dan daya saing tinggi. Sumber daya manusia sangat berperan penting dalam pencapaian tujuan organisasi.

Individual capability adalah kapasitas seseorang individu untuk melaksanakan berbagai tugas dalam menjalankan pekerjaan atau penilaian terhadap apa yang dapat dilakukan seseorang (Suprihanto, 2003:23). Individual capability sangat penting dimiliki oleh karyawan karena dengan adanya kemampuan berpikir, menganalisis, dan memahami masalah yang terjadi, karyawan akan mampu memecahkan segala permasalahan yang terjadi dalam organisasi atau perusahaan.

Menurut Rivai dalam Sriwidodo dan Haryanto (2010) kemampuan seseorang merujuk ke suatu kapasitas individu untuk mengerjakan berbagai tugas dalam suatu pekerjaan dan seluruh kemampuan seorang individu. Menurut Bapak Zendi, peran individual capability pada karyawan PT. Balindo Manunggal Bersama Palu, sebagian karyawan masih ragu-ragu dalam pengambilan keputusan tanpa melibatkan karyawan dan pimpinan langsung. Misalnya konsumen yang komplain karena kurang puas dengan hasil servis, namun karyawan tidak bisa memberi solusi dari permasalahan tersebut sehingga karyawan memerlukan bantuan dari karyawan lain atau atasan dalam penyelesaian permasalahannya. Disamping itu kurangnya pemahaman pengetahuan yang dimiliki karyawan terhadap spesifikasi dari pekerjaan yang dilaksanakan dalam menyelesaiakan tugas dan tanggung jawab yang diberikan.

Motivasi adalah energi untuk membangkitkan dorongan dalam diri (drive arousal). Disimpulkan bahwa motivasi merupakan suatu kekuatan yang ada dalam diri seseorang yang dapat mengarahkan perilaku untuk melakukan sesuatu kegiatan sesuai tujuan yang ingin dicapai. Kekuatan ini dapat dikembangkan oleh individu sendiri atau sejumlah kekuatan dari luar. Di lingkungan kerja, motivasi karyawan turut mempengaruhi hasil kinerjanya baik secara positif atau negatif. Apabila karyawan mempunyai motivasi kerja yang baik, pada umumnya akan dapat melakukan pekerjaannya dengan baik pula (Mangkunegara dalam Sriwidodo dan Haryanto (2010).

Peran motivasi karyawan pada PT. Balindo Manunggal Bersama Palu sangat penting karena motivasi akan mendorong perilaku karyawan untuk mau giat bekerja dan antusias mencapai hasil yang diharapkan. Dalam diri seseorang motivasi sangat dibutuhkan, karena tanpa adanya motivasi maka karyawan tersebut tidak akan mau melakukan pekerjaan bahkan tidak bergerak sedikitpun dari tempatnya. Menurut Bapak Zendi, hal yang memotivasi karyawan PT. Balindo Manunggal Bersama Kota Palu adalah adanya berbagai tunjangan yang diberikan perusahaan atas prestasi kerja yang diraih karyawan tersebut. Namun hal ini yang membuat karyawan tersebut bersikap egois tanpa memikirkan perasaan karyawan lain atau karyawan yang bekerja dalam satu devisi sehingga karyawan tersebut tidak menerima pendapat dari sesama rekan kerjanya bahkan menganggap bahwa dirinya yang terbaik dalam sebuah tim yang dimana ide-idenya atau gagasan-gagasannya sudah tepat dan benar. Karyawan dalam menjalin hubungan kerja yang ada di PT. Balindo Manunggal Bersama Kota Palu nampak kurang harmonis. Hal ini ditunjukkan dengan adanya karyawan malas dalam bekerja, hal ini nampak pada saat jam kerja mereka terlihat hanya menganggur bahkan ada yang tertidur dimeja kerjanya. 
Kinerja adalah hasil kerja secara kualitas dan kuantitas yang dicapai oleh seseorang pegawai dalam melaksanakan tugasnya sesuai dengan tanggung jawab yang diberikan kepadanya Mangkunegara dalam Sriwidodo dan Haryanto (2010). Sumber daya manusia yang berkualitas adalah sumber daya manusia yang berhasil dalam pelaksanaan pekerjaannya. Hal tersebut dapat dilihat dari hasil kinerja karyawan. Hasil kerja yang baik menunjukkan suatu perwujudan dari pekerjaan pegawai yang diberikan kepada perusahaannya. Dimana hasil kerja tersebut biasanya digunakan sebagai dasar penilaian terhadap kerja karyawan.

Salah satu ukuran kinerja adalah ketepatan waktu. Menurut Bapak Zendi, karyawan PT. Balindo Manunggal Bersama Kota Palu dalam melakukan tugasnya sering tidak sesuai dengan yang diharapkan perusahaan. Masih banyak keluhan pada bagian servis. Hal ini membuat konsumen bosan karena terlalu lama menunggu. Hal ini karena banyaknya servis yang harus dikerjakan menjadikan kualitas pekerjaan yang dihasilkan karyawan menjadi kurang memuaskan akibat pengerjaan yang dilakukan terburu-buru karena banyaknya daftar antrian servis dari konsumen.

Berdasarkan latar belakang yang telah diuraikan, maka identifikasi masalah penelitian adalah sebagai berikut:

1. Apakah Individual Capability dan Motivasi berpengaruh secara serempak terhadap kinerja karyawan PT. Balindo Manunggal Bersama Kota Palu?

2. Apakah Individual Capability berpengaruh secara parsial terhadap kinerja karyawan PT. Balindo Manunggal Bersama Kota Palu?

3. Apakah Motivasi berpengaruh secara parsial terhadap kinerja karyawan PT. Balindo Manunggal Bersama Kota Palu?

\section{KAJIAN LITERATUR DAN PENGEMBANGAN HIPOTESIS}

\section{Pengertian Individual Capability}

Individual Capability adalah kemampuan seseorang merujuk ke suatu kapasitas individu untuk melakukan beragam tugas dalam suatu pekerjaan. Kemampuan adalah sebuah penilaian terkini atas apa yang dapat dilakukan seseorang menurut Robbins dan Judge (2008:57). Kemampuan keseluruhan seseorang individu pada dasarnya terdiri atas dua kelompok faktor yaitu:

1. Kemampuan intelektual adalah kemampuan yang dibutuhkan untuk melakukan berbagai aktivitas mental-berpikir, menalar, dan memecahkan masalah. Ada tujuh kemampuan intelektual yaitu sebagai berikut:
a. Kecerdasan angka, yaitu kemampuan melakukan aritmatika dengan cepat dan akurat;
b. Pemahaman verbal, yaitu kemampuan memahami apa yang dibaca atau didengar dan hubungan antara kata-kata;
c. Kecepatan persepsi, yaitu kemampuan mengidentifikasi kemiripan dan perbedaan visual secara cepat dan akurat;
d. Penalaran induktif, yaitu kemampuan mengidentifikasi urutan logis dalam sebuah masalah dan kemudian memecahkan masalah tersebut;
e. Penalaran deduktif, yaitu kemampuan menggunakan logika dan menilai implikasi dari suatu argument;
f. Visualisasi spasial, yaitu kemampuan membayangkan bagaimana suatu objek akan tampak seandainya posisinya dalam ruang diubah;

g. Daya ingat, yaitu kemampuan menyimpan dan mengingat pengalaman masa lalu.

2. Kemampuan Fisik yaitu kemampuan yang memiliki makna penting khusus untuk melakukan pekerjaan yang kurang menuntut keterampilan. Misalnya pekerjaan yang menuntut stamina, kecekatan tangan, atau bakat. Ada sembilan kemampuan fisik yaitu sebagai berikut:
a. Kekuatan dinamis yaitu kemampuan memanfaatkan kekuatan otot secara berulang-ulang atau terus-menerus.


b. Kekuatan tubuh yaitu kemampuan mengenakan kekuatan otot menggunakan otot tubuh (khususnya otot perut).

c. Kekuatan statis yaitu kemampuan menggunakan kekuatan terhadap objek eksternal.

d. Kekuatan eksplosif yaitu kemampuan mengeluarkan energi maksimum dalam satu atau serangkaian tindakan eksplosif.

e. Fleksibilitas luas yaitu kemampuan menggunakan tubuh dan otot punggung sejauh mungkin.

f. Fleksibilitas dinamis yaitu kemampuan membuat gerakan-gerakan lentur yang cepat dan berulang-ulang.

g. Koordinasi tubuh yaitu kemampuan mengoordinasikan tindakan secara bersamaan dari bagian-bagian tubuh yang berbeda.

h. Keseimbangan yaitu kemampuan mempertahankan keseimbangan meskipun terdapat gaya yang mengganggu keseimbangan.

i. Stamina yaitu kemampuan mengerahkan upaya maksimum yang membutuhkan usaha berkelanjutan.

\section{Pengertian Motivasi}

Motivasi berasal dari kata latin "Movere" yang berarti dorongan, daya pengerak atau kekuatan yang menyebabkan suatu tindakan atau perbuatan. Menurut Robbins dalam Wibowo (2007:322) menyatakan bahwa motivasi adalah proses yang menunjukkan intensitas individu, arah, dan ketekunan dari upaya menuju pencapaian tujuan. Teori kebutuhan McClelland (McClelland's theory of needs) dalam Bangun (2012:325-326) disebut juga dengan teori motivasi prestasi. Menurut teori ini, ada tiga komponen dasar yang dapat digunakan untuk memotivasi orang bekerja, yaitu sebagai berikut:

1. Kebutuhan akan Prestasi (need for achievement) tercermin pada orientasinya dalam mencapai tujuan organisasi. Seseorang yang mempunyai motivasi berprestasi, akan menyukai pekerjaan yang menantang. Mereka tidak percaya kepada nasib baik dalam mencapai sesuatu, karena segala sesuatu dapat dicapai melalui kerja keras. Mereka menyukai pekerjaan yang cukup sulit, menantang, dan realistis. Mereka percaya kepada kemampuannya sendiri dalam mengerjakan pekerjaanya untuk mencapai sesuatu yang diharapkan. Mereka tidak terlalu mengharapkan bantuan orang lain dalam mengerjakan pekerjaanya, melainkan yakin atas kemampuannya sendiri. Kalaupun membutuhkan bantuan orang lain, namun memperoleh bantuan dari orang yang mempunyai hubungan dengan pekerjaanya.

2. Kebutuhan akan Afiliasi (need for affiliation) tercermin pada keinginan sesorang untuk menciptakan, memelihara, dan menghubungkan suasana kebatinan dan perasaan yang saling menyenangkan antar sesama manusia dalam organisasi. orang yang memiliki kebutuhan tinggi untuk berafiliasi biasanya senang kasih sayang dan cenderung menghindari kekecewaan karena ditolak oleh suatu kelompok sosial. Tujuan utama dari orang yang dengan motivasi berafiliasi adalah memperoleh persahabatan dengan rekannya dalam organisasi, lebih menyukai situasi kooperatif dari pada persaingan, dan sangat menyukai hubungan yang melibatkan derajat pemahaman timbal balik yang tinggi. Bagi orang yang didominasi oleh motif ini disenangi oleh pimpinan dan rekan sekerja, dan umumnya orang yang demikian tidak terlalu mementingkan prestasi dalam organisasi melainkan lebih mementingkan persahabatan.

3. Kebutuhan akan Kekuasaan (need for power) orang-orang yang memiliki kebutuhan yang tinggi untuk berkuasa akan menaruh perhatian besar untuk dapat memengaruhi dan mengendalikan orang lain dalam organisasi. Orang-orang seperti ini mempunyai hasrat untuk memengaruhi dan mengendalikan orang lain dalam organisasi dalam mencapai tujuannya. Pada umumnya, orangorang yang memiliki tingkat kebutuhan yang tinggi terhadap kekuasaan lebih menyukai situasi dimana mereka dapat memperoleh dan mempertahankan pengendalian sarana untuk memengaruhi 
orang lain dalam organisasi. Mereka suka berada dalam posisi kedalam memberikan saran dan pendapat, serta menjadikan orang lain sebagai alat dalam mencapai tujuan organisasi.

\section{Pengertian Kinerja}

Menurut Mangkunegara dalam Susanty (2012), istilah kinerja berasal dari kata job performance atau actual performance (prestasi kerja atau prestasi sesungguhnya yang dicapai seseorang) yaitu hasil kerja secara kualitas dan kuantitas yang dicapai oleh seorang pegawai dalam melaksanakan tugasnya sesuai dengan tanggung jawab yang diberikan kepadanya. selanjutnya menurut Bangun (2012:234) dalam penilaian kinerja karyawan, standar pekerjaan harus dapat diukur dan dipahami secara jelas melalui:

1. Jumlah pekerjaan, yaitu jumlah pekerjaan yang dihasilkan individu atau kelompok sebagai persyaratan yang menjadi standar pekerjaan. Setiap pekerjaan memiliki persyaratan yang berbeda sehingga menuntut karyawan harus memenuhi persyaratan tersebut baik pengetahuan, keterampilan, maupun kemampuan yang sesuai. Berdasarkan persyaratan pekerjaan tersebut dapat diketahui jumlah karyawan yang dibutuhkan untuk dapat mengerjakannya, atau setiap karyawan dapat mengerjakan berapa unit pekerjaan.

2. Kualitas pekerjaan, yaitu setiap karyawan dalam perusahaan harus memenuhi persyaratan tertentu untuk dapat menghasilkan pekerjaan sesuai kualitas yang dituntut suatu pekerjaan tertentu. Setiap pekerjaan memiliki standar kualitas tertentu yang harus disesuaikan oleh karyawan untuk dapat mengerjakannya sesuai ketentuan. Karyawan memiliki kinerja baik bila dapat menghasilkan pekerjaan sesuai persyaratan kualitas yang dituntut pekerjaan tersebut.

3. Ketepatan Waktu, yaitu jenis pekerjaan tertentu harus diselesaikan tepat waktu, karena memiliki ketergantungan atas pekerjaan lainnya. Jadi, apabila pekerjaan pada suatu bagian tertentu tidak selesai tepat waktu akan menghambat pekerjaan pada bagian lain, sehingga mempengaruhi jumlah dan kualitas hasil pekerjaan. Demikian pula, suatu pekerjaan harus diselesaikan tepat waktu karena batas waktu pesanan pelanggan dan penggunaan hasil produksi. Pelanggan sudah melakukan pemesanan produk sampai batas waktu tertentu. Untuk memenuhi tuntutan tersebut, pihak perusahaan harus menghasilkannya tepat waktu. Suatu jenis produk tertentu hanya dapat digunakan sampai batas waktu tertentu saja, ini menuntut agar diselesaikan tepat waktu, karena akan berpengaruh atas penggunaannya. Pada dimensi ini karyawan dituntut untuk dapat menyelesaikan pekerjaan tepat waktu.

4. Kehadiran, yaitu suatu jenis pekerjaan tertentu menuntut kehadiran karyawan dalam mengerjakannya sesuai waktu yang ditentukan. Ada tipe pekerjaan yang menuntut kehadiran karyawan selama delapan jam sehari untuk lima hari kerja seminggu. Kinerja karyawan ditentukan oleh tingkat kehadiran karyawan dalam mengerjakannya.

5. Kemampuan kerja sama, tidak semua pekerjaan dapat diselesaikan oleh satu orang karyawan saja. Untuk jenis pekerjaan tertentu mungkin harus diselesaikan oleh dua orang karyawan atau lebih, sehingga membutuhkan kerja sama antarkaryawan sangat dibutuhkan. Kinerja karyawan dapat dinilai dari kemampuannya bekerja sama dengan rekan sekerja lainnya.

\section{Kerangka Pemikiran}

Pengaruh individual capability dan Motivasi terhadap kinerja karyawan PT. Balindo Manunggal Bersama Kota Palu dapat dijelaskan melalui kerangka pemikiran, untuk lebih jelasnya dapat dilihat pada gambar berikut: 


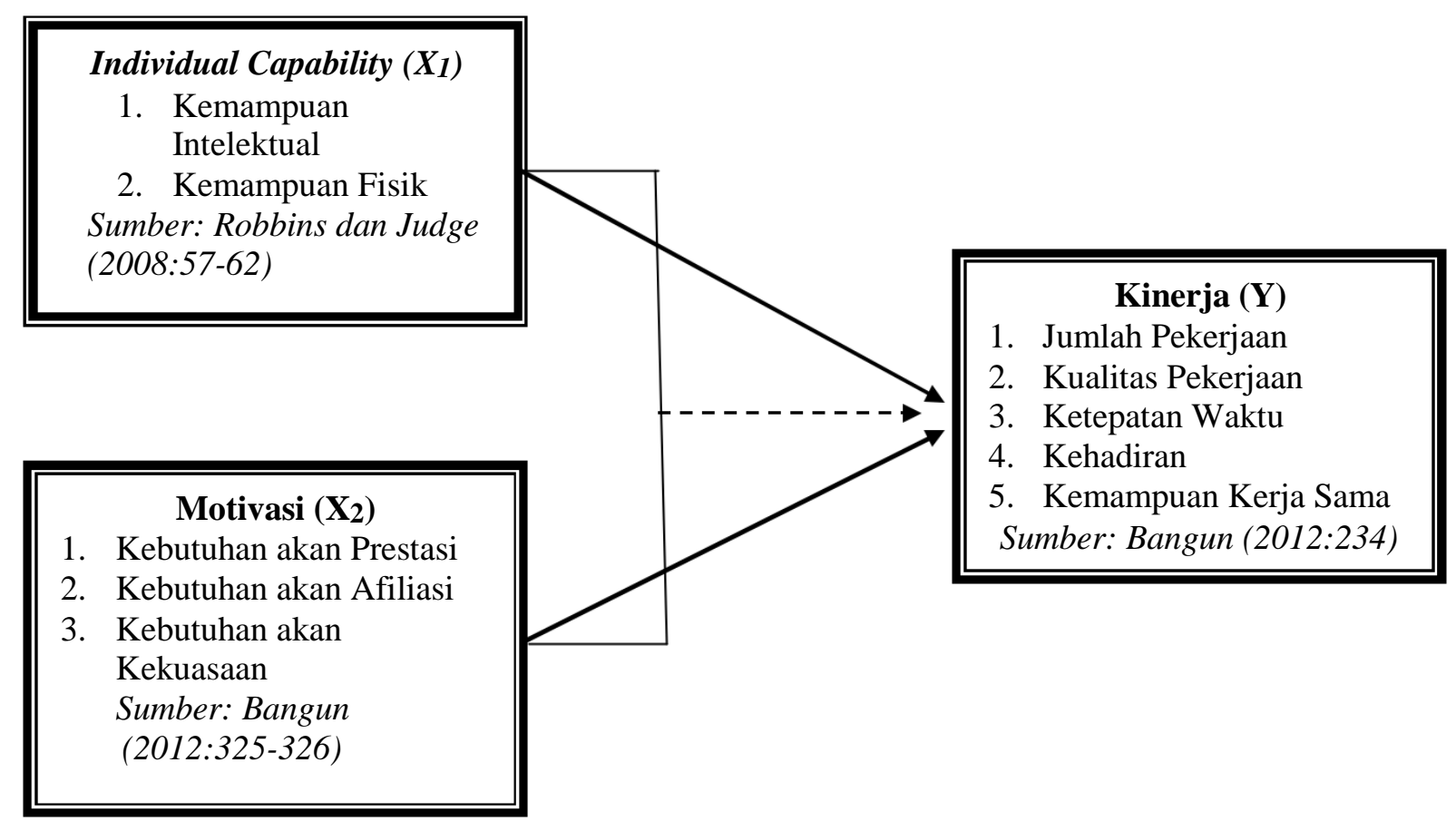

\section{Gambar 1 Kerangka Pemikiran Penelitian}

\footnotetext{
- - - $\rightarrow$ : Pengaruh secara serempak (pengaruh serempak variabel bebas)

$\longrightarrow$ : Pengaruh secara Parsial (pengaruh masing-masing variabel bebas)
}

\section{Hipotesis}

Berdasarkan permasalahan dan kajian pustaka yang dikemukakan maka dapat disusun hipotesis penelitian sebagai berikut:

1. Individual Capability dan Motivasi berpengaruh secara serempak terhadap kinerja karyawan PT. Balindo Manunggal Bersama Kota Palu.

2. Individual Capability berpengaruh secara parsial terhadap kinerja karyawan PT. Balindo Manunggal Bersama Kota Palu.

3. Motivasi berpengaruh secara parsial terhadap kinerja karyawan PT. Balindo Manunggal Bersama Kota Palu.

\section{METODE PENELITIAN}

Penelitian ini menggunakan penelitian kuantitatif yang merupakan penelitian yang bertujuan untuk menjelaskan hubungan antara dua variabel atau lebih. Penelitian ini menggunakan populasi dan sampel, di mana populasi diartikan sebagai wilayah generalisasi yang terdiri atas: obyek/subyek yang mempunyai kualitas dan karakteristik tertentu yang ditetapkan oleh peneliti untuk dipelajari dan kemudian ditarik kesimpulannya, (Sugiyono, 2014:115).

Sampel pada penelitian ini menggunakan sampling jenuh. Sampling jenuh adalah teknik penentuan sampel bila semua anggota populasi digunakan sebagai sampel. Istilah lain sampel jenuh adalah sensus (Sugiyono, 2014:122-123). Sampel penelitian ini adalah seluruh pegawai di PT. Balindo Manunggal Bersama Kota Palu. Dimana jumlah pegawai di PT. Balindo Manunggal Bersama Palu berjumlah 32 orang. 
Tabel 1

Data Karyawan PT. Balindo Manunggal Bersama Kota Palu Masa Kerja 2 Tahun

\begin{tabular}{|c|l|c|}
\hline No & \multicolumn{1}{|c|}{ Divisi } & Jumlah Karyawan \\
\hline 1 & General Manajer & 1 \\
\hline 2 & Sales & 7 \\
\hline 3 & Spare Part & 8 \\
\hline 4 & Mekanik $\quad$ Jumlah & 8 \\
\hline 5 & Bagian Umum & 32 \\
\hline \multicolumn{2}{|c|}{} \\
\hline
\end{tabular}

\section{HASIL DAN PEMBAHASAN}

\section{Hasil Penelitian}

Penelitian ini bertujuan untuk mengetahui besarnya pengaruh baik secara simultan dan parsial antara motivasi kerja dan kompensasi terhadap kinerja karyawan pada PT. Balindo Manunggal Bersama Kota Palu. Serta untuk mengetahui dari beberapa variabel independen, variabel mana yang paling berpengaruh dominan terhadap kinerja karyawan pada PT. Balindo Manunggal Bersama Kota Palu.

Kebenaran hipotesis yang diajukan dalam penelitian ini diuji menggunakan metode analisis regresi linear berganda dan untuk menguji hipotesis yang telah dirumuskan, digunakan uji $\mathrm{F}$ dan uji t. Hasil pengujian hipotesis keseluruhan variabel penelitian dilakukan dengan menggunakan program SPSS For Windows Release 22.0. Adapun hasil analisis regresi tersebut dapat dilihat dalam tabel di bawah ini:

Tabel 2

Hasil Perhitungan Regresi Linear Berganda

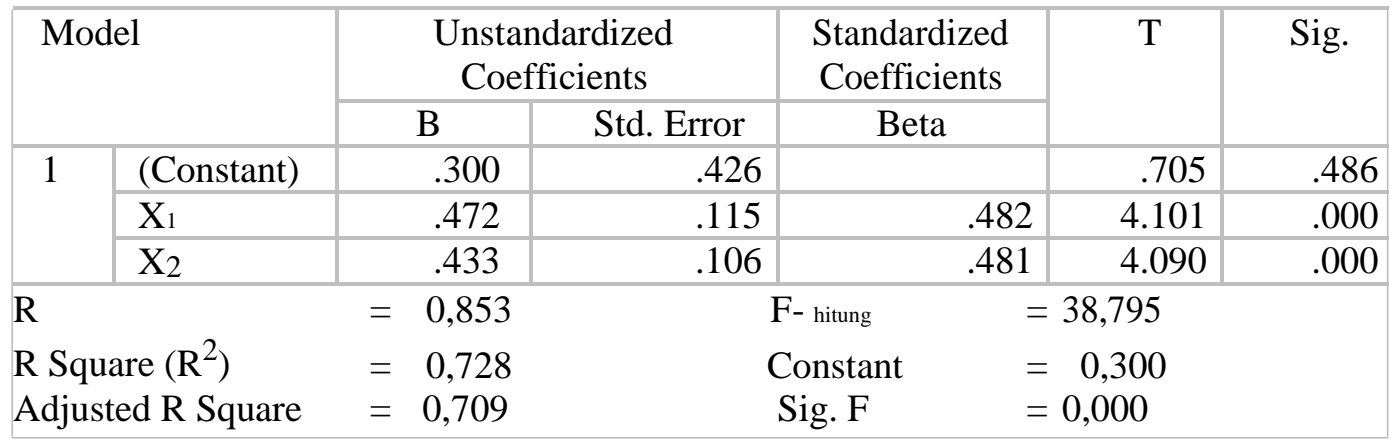

Berdasarkan nilai dari tabel 2 di atas, maka persamaan regresi linear berganda dapat dirumuskan sebagai berikut:

$$
\mathrm{Y}=0,300+0,472 \mathrm{X} 1+0,433 \mathrm{X}_{2}+\mathrm{e}
$$

\section{Pengujian Hipotesis}

Pengaruh signifikan secara serempak maupun secara parsial dari variabel independen (Individual Capability dan Motivasi) terhadap variabel dependen (Kinerja) dapat dilihat menggunakan uji $\mathrm{F}$ dan uji t. Penjelasan lebih lengkapnya dapat dilihat berikut.

\section{Uji F (Pengujian Hipotesis Secara Serempak)}

Uji F (serempak) adalah suatu metode untuk melihat apakah variabel independen (Individual Capability dan Motivasi) yang diteliti mempunyai pengaruh secara serempak terhadap variabel dependen (Kinerja). Untuk lebih jelasnya dapat dilihat pada tabel berikut: 
Tabel 3

Hasil Pengujian Serempak (Uji F)

\begin{tabular}{|l|l|r|r|r|r|r|}
\hline \multicolumn{2}{|l|}{ Model } & $\begin{array}{c}\text { Sum of } \\
\text { Squares }\end{array}$ & \multicolumn{1}{c|}{ Df } & $\begin{array}{c}\text { Mean } \\
\text { Square }\end{array}$ & F & Sig. \\
\hline \multirow{2}{*}{1} & Regression & 5.158 & 2 & 2,579 & 38.795 & $.000^{\mathrm{b}}$ \\
\cline { 2 - 8 } & Residual & 1.928 & 29 & .066 & & \\
\cline { 2 - 8 } & Total & 7.087 & 31 & & & \\
\hline
\end{tabular}

Berdasarkan hasil uji regresi pada tabel 3 di atas, diperoleh Fhitung sebesar 38,795 dengan tingkat signifikansi $(0,000)<(0,05)$, yang dapat diartikan bahwa variabel Individual Capability $\left(\mathrm{X}_{1}\right)$ dan Motivasi $\left(\mathrm{X}_{2}\right)$ secara serempak berpengaruh signifikan terhadap variabel kinerja (Y). Dimana semakin kuat pengaruh dari variabel Individual Capability dan Motivasi maka akan semakin tinggi kinerja karyawan pada PT. Balindo Manunggal Bersama Kota Palu, sehingga berdasarkan hasil tersebut maka dapat disimpulkan bahwa $\mathrm{H}_{0}$ ditolak dan $\mathrm{H}_{\mathrm{a}}$ diterima.

\section{Uji t (Pengujian Hipotesis Secara Parsial)}

Uji t digunakan untuk mengetahui apakah variabel independen yakni individual capability dan motivasi yang diteliti memiliki pengaruh secara parsial terhadap variabel dependen yakni kinerja. Untuk lebih jelasnya dapat dilihat pada tabel berikut:

Tabel 4

Hasil Pengujian Parsial

\begin{tabular}{|c|c|c|c|c|c|c|}
\hline \multirow{2}{*}{\multicolumn{2}{|c|}{ Model }} & \multicolumn{2}{|c|}{$\begin{array}{l}\text { Unstandardized } \\
\text { Coefficients }\end{array}$} & $\begin{array}{l}\text { Standardized } \\
\text { Coefficients }\end{array}$ & \multirow[t]{2}{*}{$\mathrm{t}$} & \multirow[t]{2}{*}{ Sig. } \\
\hline & & B & Std. Error & Beta & & \\
\hline \multirow[t]{3}{*}{1} & (Constant) & .300 & .426 & & .705 & .486 \\
\hline & $\mathrm{X}_{1}$ & .472 & .115 & .482 & 4.101 & .000 \\
\hline & $\mathrm{X}_{2}$ & .433 & .106 & .481 & 4.090 & .000 \\
\hline
\end{tabular}

Uji t dilakukan dengan membandingkan nilai t signifikansi lebih kecil dari $\alpha(0,05)$ maka dapat dipastikan bahwa variabel independen berpengaruh signifikan terhadap variabel dependen, sebaliknya jika nilai t signifikansi lebih besar dari $\alpha(0,05)$ maka dapat dipastikan bahwa variabel independen berpengaruh tidak signifikan terhadap variabel dependen, dapat dijelaskan hasil uji t dari variabel independen adalah sebagai berikut.

\section{Pengaruh Individual Capability (X1) Terhadap Kinerja (Y)}

Variabel Individual Capability memiliki tingkat signifikansi t sig. $(0,000)<\alpha(0,05)$. Hal ini bermakna secara parsial variabel Individual Capability di tempat kerja berpengaruh signifikan terhadap kinerja karyawan pada PT. Balindo Manunggal Bersama Kota Palu. Berdasarkan hasil di atas, maka hipotesis kedua untuk variabel Individual Capability di tempat kerja dalam penelitian yang telah dilakukan dalam hal ini terbukti $\left(\mathrm{H}_{\mathrm{o}}\right.$ ditolak dan $\mathrm{H}_{\mathrm{a}}$ diterima). Artinya variabel Individual Capability di tempat kerja berpengaruh signifikan terhadap kinerja karyawan pada PT. Balindo Manunggal Bersama Kota Palu.

\section{Pengaruh Motivasi (X2) Terhadap Kinerja (Y)}

Variabel Motivasi memiliki tingkat signifikansi t sig. $(0,000)<\alpha(0,05)$. Hal ini bermakna secara parsial variabel Motivasi di tempat kerja berpengaruh signifikan terhadap kinerja karyawan pada PT. Balindo Manunggal Bersama Kota Palu. Berdasarkan hasil di atas, maka hipotesis ketiga untuk variabel Motivasi di tempat kerja dalam penelitian yang telah dilakukan dalam hal ini terbukti $\left(\mathrm{H}_{\mathrm{o}}\right.$ 
ditolak dan $\mathrm{H}_{\mathrm{a}}$ diterima). Artinya variabel motivasi di tempat kerja berpengaruh signifikan terhadap kinerja karyawan pada PT. Balindo Manunggal Bersama Kota Palu.

\section{Pembahasan}

\section{Individual Capability dan Motivasi Berpengaruh Terhadap Kinerja Karyawan}

Hipotesis pertama dalam penelitian ini diperoleh Fhitung sebesar 38,795 dengan tingkat signifikansi $(0,000)<(0,05)$, yang dapat diartikan bahwa Individual Capability dan Motivasi secara serempak berpengaruh signifikan terhadap kinerja karyawan pada PT Balindo Manuggal Bersama Kota Palu. Hal ini membuktikan bahwa kinerja karyawan pada PT. Balindo Manunggal Bersama Kota Palu dapat ditingkatkan bila ada pengaruh dari kedua variabel tersebut. Melihat hasil tersebut, maka dapat dikatakan bahwa kinerja karyawan dapat dipenrauhi oleh individual capability dan motivasi sehingga karyawan harus memilikinya.

Peneliti memandang bahwa individual capability dan motivasi yang dimiliki karyawan bertujuan untuk meningkatkan kinerja karyawan. Variabel individual capability dan motivasi di atas sebagai variabel yang dinilai memberikan pengaruh signifikan terhadap kinerja karyawan pada PT. Balindo Manunggal Bersama Kota Palu. Hal ini didasari pada realita hasil penelitian lapangan yang mampu membuktikan secara empiris adanya kekuatan hubungan dan pengaruh dari variabel individual capability dan motivasi yang diamati secara serempak mempengaruhi kinerja karyawan pada PT. Balindo Manunggal Bersama Kota Palu. Nilai R sebesar 0,853 yang berarti individual capability dan motivasi mampu menjelaskan kinerja karyawan PT. Balindo Manunggal Bersama Kota Palu sebesar 85,3\% atau bisa diartikan bahwa kinerja karyawan yang diukur melalui individual capability dan motivasi mampu menjelaskan seberapa besar kinerja karyawan PT. Balindo Manunggal Bersama Kota Palu.

Sesuai dengan teori kinerja menurut Trisnaningsih dalam Ongkorahardjo (2008) bahwa kinerja adalah suatu hasil karya yang dicapai seseorang dalam melaksanakan tugas-tugas yang dibebankan kepadanya yang didasarkan atas kecakapan, pengalaman, dan kesungguhan yang diukur dengan mempertimbangkan kualitas, kuantitas, dan ketepatan waktu. Dalam hal tersebut kecakapan yang dimaksud adalah Individual capability. Menurut Hagel dan Brown dalam Hendrawan (2012:19) mengartikan kapabilitas sebagai kemampuan untuk memobilisasi sumber daya untuk menghasilkan nilai yang melebihi ongkos. Individual Capability yang dimaksud adalah kemampuan seseorang dalam melakukan pekerjaan yang ditunjang dengan sumber kekuatan yang ada dalam diri karyawan sehingga akan berpengaruh terhadap hasil kerja karyawan. Dalam hal ini perusahaan dituntut agar mampu memobilisasi SDM yang dimiliki agar bekerja sesuai dengan standar perusahaan sehingga mampu meningkatkan kinerja perusahaan.

Hal lain yang mempengaruhi kinerja adalah kesungguhan dimana yang dimaksud adalah motivasi. Motivasi adalah energi untuk membangkitkan dorongan dalam diri (drive arousal). Disimpulkan bahwa motivasi merupakan suatu kekuatan yang ada dalam diri seseorang yang dapat mengarahkan perilaku untuk melakukan sesuatu kegiatan sesuai tujuan yang ingin dicapai. (Mangkunegara dalam Sriwidodo dan Haryanto (2010). Pemberian motivasi terhadap karyawan akan mampu menggerakkan keinginannya untuk bersungguh-sungguh bekerja sesuai dengan standar kerja yang ditetapkan perusahaan.

\section{Individual Capability Berpengaruh Terhadap Kinerja Karyawan}

Hipotesis kedua dalam penelitian ini individual capability $\left(\mathrm{X}_{1}\right)$ memiliki tingkat signifikansi t sig. $(0,000)<\alpha(0,05)$. Hal ini bermakna secara parsial variabel Individual Capability di tempat kerja berpengaruh signifikan terhadap kinerja karyawan pada PT. Balindo Manunggal Bersama Kota Palu. Dalam penelitian ini, peneliti memandang bahwa individual capability yang dimiliki karyawan bertujuan untuk meningkatkan kinerja karyawan. Berdasarkan penelitian yang dilakukan terhadap karyawan dan melihat hasil tabulasi data dan jawaban responden, individual capability yang dimiliki 
karyawan sudah sangat baik. Seperti halnya kemampuan intelektual dimana karyawan dituntut agar mampu menyelesaikan masalah ditempat kerja, mampu menelaah setiap saran yang berhubungan dengan pekerjaan dan mampu membedakan informasi yang diterimanya. Selain itu kemampuan fisik, dimana karyawan harus mampu menyelesaikan pekerjaan yang membutuhkan stamina, cekatan dalam melakukan pekerjaan, dan terampil dalam menyelesaikan pekerjaan.

Peran pimpinan dalam hal ini sangat penting, dimana pimpinan harus mampu mengelola sumber daya manusia (karyawan) yang dimilikinya menjadi SDM yang berkualitas dengan memberikan pelatihan sesuai dengan devisi yang ditempati karyawan sehingga menambah pengetahuan karyawan yang menjadikan karyawan tersebut memiliki nilai dan mampu bersaing didunia kerja. Sebaliknya, apabila pimpinan tidak mampu mengelola SDM yang ada, maka akan menurunkan kinerja perusahaan, karena keberhasilan sebuah perusahaan terletak pada kemampuan karyawanya dalam mengelola perusahaan.

\section{Motivasi Berpengaruh Terhadap Kinerja Karyawan}

Hipotesis ketiga dalam penelitian ini motivasi $\left(\mathrm{X}_{2}\right)$ memiliki tingkat signifikansi t sig. $(0,000)<\alpha$ $(0,05)$. Hal ini bermakna secara parsial variabel motivasi di tempat kerja berpengaruh signifikan terhadap kinerja karyawan pada PT. Balindo Manunggal Bersama Kota Palu. Peneliti memandang bahwa dalam penelitian ini implementasi pemberian motivasi yang dilakukan pimpinan untuk meningkatkan kinerja karyawan sangat baik. Hal ini dapat dibuktikan dari hasil interpretasi mean pada variabel motivasi. Seperti halnya pada kebutuhan akan prestasi, dapat dilihat dari berbagai macam hal, yaitu mampu menyelesaikan pekerjaan yang sulit, suka pekerjaan yang menantang, dan bekerja sesuai realita yang ada dilapangan. Disisi lain, kebutuhan akan afiliasi dapat dilihat dari membina persahabatan sesama rekan kerja, menyukai sikap kooperatif antar rekan kerja, dan menyukai hubungan timbal balik antar rekan kerja. Selain itu, kebutuhan akan kekuasaan dilihat dari segi seberapa besar keinginan karyawan menjadi ketua dalam suatu kelompok kerja, seberapa mampu karyawan mempertahankan posisinya, dan seberapa mampu karyawan memengaruhi karyawan lainnya.

Pimpinan memotivasi karyawan dengan memberikan hadiah kepada karyawan yang berprestasi. Hal itu merupakan upaya dalam meningkatkan kinerja karyawan PT. Balindo Manunggal Bersama Kota Palu. Adanya motivasi positif tersebut, maka karyawan akan memiliki semangat dalam melakukan pekerjaannya. Karena pada umumnya seorang karyawan akan merasa senang jika diberi suatu penghargaan atas hasil kerjanya. Oleh sebab itu, pimpinan harus memberikan perhatian lebih terutama dalam pemberian motivasi kepada karyawannya karena semakin tinggi motivasi yang dimiliki karyawan maka semakin tinggi pula kinerja karyawan.

Kebanggaan seorang karyawan pada pekerjaannya menjadi motivasi positif seseorang. Kebanggan tersebut dapat diwujudkan dengan seberapa mampu seorang karyawan menghadapi tantangan sehingga memperoleh hasil atas prestasi kerja yang diraihnya. Pemberian tantangan tersebut bertujuan untuk memberi rasa percaya perusahaan terhadap karyawannya sehingga karyawan merasa keberadaanya dalam perusahaan tersebut dibutuhkan oleh perusahaan.

\section{KESIMPULAN DAN SARAN}

\section{Kesimpulan}

Berdasarkan hasil pembahasan penelitian yang telah dikemukakan di atas, maka penulis mengambil beberapa kesimpulan dari hasil penelitian ini sebagai berikut:

1. Individual capability dan motivasi berpengaruh secara serempak terhadap kinerja karyawan pada PT. Balindo Manunggal Bersama Kota Palu.

2. Individual capability berpengaruh signifikan terhadap kinerja karyawan pada PT. Balindo Manunggal Bersama Kota Palu. 
3. Motivasi berpengaruh signifikan terhadap kinerja karyawan pada PT. Balindo Manunggal Bersama Kota Palu.

\section{Saran}

Berdasarkan hasil penelitian serta hal-hal yang terkait dengan keterbatasan penelitian, maka peneliti memberikan saran sebagai berikut:

1. Untuk meningkatkan individual capability, hendaknya PT. Balindo Manunggal Bersama Kota Palu memberikan pelatihan-pelatihan yang menambah pengetahuan dan kemampuan yang dimiliki karyawan khususnya pada kemampuan fisik sesuai dengan bidang teknisnya. Misalnya, pemberian magang ke perusahaan pusat sehingga karyawan memiliki pengalaman baru untuk diterapkan diperusahaannya.

2. Untuk meningkatkan motivasi, hendaknya PT. Balindo Manunggal Bersama Kota Palu memberikan motivasi yang mampu membangkitkan semangat kerja karyawan yaitu dengan memberikan promosi jabatan yang lebih tinggi atas prestasi kerja yang diraih karyawan sehingga karyawan termotivasi untuk lebih giat bekerja agar meraih kekuasaan yang ditawarkan perusahaan. Misalnya, karyawan yang bekerja menjadi supervisor selama 5 tahun dipromosikan menjadi manajer.

3. Untuk meningkatkan kinerja, hendaknya PT. Balindo Manunggal Bersama Kota Palu memperhatikan kinerja karyawan dengan mengadakan kegiatan yang mampu meningkatkan kinerja karyawan. Misalnya melakukan kegiatan seminar mengenai manajemen waktu, dengan memberi pemahaman mengenai manajemen waktu, maka karyawan akan lebih paham dan mampu menerapkanya dalam mengerjakan pekerjaan.

4. Diharapkan kepada peneliti selanjutnya, agar dapat mengembangkan penelitian ini dengan mengkaji variabel lain yang juga memiliki pengaruh terhadap kinerja karyawan.

\section{REFERENSI}

Bangun, Wilson. (2012). Manajemen Sumber Daya Manusia. Jakarta: Erlangga.

Handoko, T Hani. (2011). Manajemen Personalia dan Sumberdaya Manusia. Yogyakarta: BPFEYogyakarta.

Hendrawan, Sanerya et.al. (2012). Pengembangan Human Capital Perspektif Nasional, Regional, dan Global. Yogyakarta: Graha Ilmu.

Ongkorahardjo, Martina Dwi Puji Astri, Antonius Susanto, dan Dyna Rachmawati. (2008). "Ananlisis Pengaruh Human Capital Terhadap Kinerja Perusahaan (Studi Empiris pada Kantor Akuntan Publik di Indonesia)". Jurnal Akuntansi dan Keuangan, Vol.10, No.1.

Robbins, Stephen P, dan Timothy A. Judge. (2008). Perilaku Organisasi. Jakarta: Salemba Empat.

Sriwidodo dan Haryanto. (2010). Pengaruh Kompetensi, Motivasi, Komunikasi Dan Kesejahteraan Terhadap Kinerja Pegawai Dinas Pendidikan. Jurnal Manajemen Sumberdaya Manusia, Vol. 4, No.1.

Sugiyono, (2014). Metode Penelitian Bisnis. Bandung: Alfabeta.

Suprihanto, John, dkk. (2003). Perilaku Organisasional. Sekolah Tinggi Ilmu Ekonomi YKPN, Yogyakarta.

Susanty, Aries dan Sigit Wahyu Baskoro. (2012). Terhadap Disiplin Kerja Serta Dampaknya Pada Kinerja Karyawan (Studi Kasus Pada PT. PLN (Persero) APBD Semarang). J@ TI Undip, Vol VII, No.2. 
Mariani, N.M.

Swastari, Dian. (2013). Analisis Penerapan Human Capital Management Terhadap Kinerja Karyawan Studi Pada PT. Telkomsel Branch Purwokerto. Jurnal. Fakultas Ekonomi Universitas Dian Nuswantoro Semarang, Semarang.

Wibowo. (2007). Manajemen Kinerja. Edisi kelima. Jakarta: PT. Raja Grafindo Persada. 